\title{
The Phylogenetic Classification of Flowering Plants.
}

\section{By JoHn Parkin.}

THE epithet, phylogenetic, in the above title might be considered superfluous, as all biologists are agreed that a taxonomic arrangement of any group of plants or animals should, so far as possible, follow evolutionary lines; after that, its convenience should be considered. Strange to say, up to the present, no arrangement of the Flowering Plants (Angiosperms), which has been generally adopted in text-books or used for floras, merits the term phylogenetic-hence the insertion of the word in the heading to this article.

Of the two chief classifications in use at the present time, that of Bentham \& Hooker never outwardly professed to be a phylogenetic arrangement; while that of Engler, though apparently launched as such, has proved unworkable from the evolutionary point of view, and bears the impress of being artificial in its main contention, namely, the primitiveness of the apetalous unisexual flower of few parts. Surely, then, the time is ripe- some would say long overdue-for the introduction of a new system embodying up-to-date views respecting the evolution and possible origin of the flower. A strong movement in this direction is being taken by Mr. J. Hutchinson of the Kew Herbarium, and a series of papers by him, entitled "Contributions towards a Phylogenetic Classification of Flowering Plants," are appearing in the Kew Bulletin..$^{1}$ It is the purpose of this article to invite the attention of botanists to these papers, and at the same time to review briefly the general position and trend of this department of botany.

Kew has never adopted Engler's system. It has hitherto remained faithful to that of Bentham \& Hooker as expressed in their classical work the " Genera Plantarum." But at last it shows unmistakable signs of breaking away and of inaugurating a new arrangement on logical lines. As it controls largely the systematic botany of the Empire, such a system is bound to make headway; so it is incumbent on those botanists who are interested and sympathetic to give it their attention and helpful criticism, in order that it may benefit thereby before it becomes too stereotyped. A new system cannot be fully worked out all at once. Hutchinson's method of publication by a series of preliminary papers gives ample opportunity for this kind of criticism, and we are sure that such comments will be much welcomed. $\mathrm{He}$ has already enunciated his principles and dealt in detail with some of the important families ${ }^{2}$ composing the Ranales upon which his system is based ; and last year he published his proposed rearrangement of the orders (cohorts) and families constituting the Archichlamydeæ of Engler (the equivalent of the Polypetalæ and Apetalæ combined of older classifications). These papers are not only worthy of the attention of the taxonomist, but also of the general botanist. They infuse new life into a department of botany which at times is apt to savour too much of the kind of material with which the systematist usually deals.

It is well to remember that, prior to the publication of "The Origin of Species," systematic botany was under

1 Kew Bulletin, pp. 65 and 24I, I923; pp. 49 and $\mathrm{Ir}_{4}, \mathrm{r} 924$.

2 Ranunculaceæ, Winteraceæ (detached from the Magnoliaceæ) and Anonaceæ.

NO. 2888, vOL. I I 5$]$ the influence of the dogma of the constancy of species. Since systematists then adhered to the belief that the different forms of plants were special creations, the idea of primitiveness was not involved-it had no meaning. Consequently it was largely optional as to which group was given the initial place in a system. Two chief tendencies, however, are noticeable with respect to the Dicotyledons-one the placing of plants with incomplete flowers lacking petals (the Apetalæ) first, and the other, the putting of the Ranalean families (Ranunculaceæ, Magnoliaceæ, etc.) into this prominent position. One may be said to have culminated in the classification of Engler and the other in that of Bentham \& Hooker. The former system in a measure owed its initiation to Brongniart, who in 1843 suggested that the apetalous division of Jussieu ought to be abandoned on the ground that these flowers are an imperfect state of polypetaly. This was a remarkable step forward on the part of this French botanist, considering it was ventured at a time when the principle of evolution was not generally accepted. The German school later, while putting into practice to some extent Brongniart's suggestion, e.g. in uniting the apetalous Chenopods with the petalous Caryophylls-the stock examplemade no attempt to interpolate the whole of the apetalous families among the Polypetalæ; but instead diverged on novel lines by postulating, or at least inferring, the primitiveness of unisexual flowers of few parts, such as we find in the catkin-bearing trees and Casuarina.

Bentham \& Hooker made no attempt to apply Brongniart's principle. They adopted the Candollean classification, modifying it in certain respects. De Candolle was the first to commence a dicotyledonous sequence with the Ranalean families, and Bentham \& Hooker followed suit. They both treat the apetalous families as a sort of miscellaneous appendage, after dealing with the whole of the Polypetalæ and Sympetalæ. It is interesting to note that no phylogenetic significance was attached to the position assigned to the Ranalean families. ${ }^{3}$ Intuitively they appear to have alighted upon the primitive group.

Hutchinson's aim is to reconcile, as it were, the two opposing systems at present in use, on one hand, by taking the Ranalean families as his base and, on the other hand, by making full use of Brongniart's principle. He considers such a system, broadly speaking, phylogenetically sound, and with this the present writer is in agreement.

Among British systematists Engler's system has met with tardy acceptance. The conservatism of Kew has probably been the restraining influence-a conservatism which now appears justified. In universities, however, it has by now been generally adopted, apparently without criticism. Doubtless Engler's great name, coupled with the publication in association with Prantl of that colossal, finely conceived and beautifully illustrated work "Die Natürlichen Pflanzenfamilien," which marks an epoch in botanical literature, prevailed upon botanists to accept the

3 See, in this connexion, a letter dated May 13, I907, from Sir J. D. Hooker to Dr. Newell Arber, reproduced in "Life and Letters of Sir J. D. Hooker" (Leonard Huxley, London, I9I8, vol. I1, p. 22). 
system. It appears to me to be a most difficult one upon which to frame a course of instruction in what is known, for want of a better term, as systematic botany. Perhaps, though accepted in the abstract, it is largely ignored in the class and lecture-room! But there is the self-taught botanist to consider, and he has only textbooks on Englerian lines for his guidance.

Let us glance at the difficulties in the way of regarding Engler's system as even remotely phylogenetic. It is based essentially on the character of the perianth : the mere fact of relying on one organ for his sequence arouses suspicion as to its naturalness. He commences with families possessing flowers without a perianth or with sepals only, passes to those with a petaloid perianth, and then to those with a definite calyx and corolla. There is no evidence of the perianth arising in this de novo fashion, as outgrowths from the floral axis, as presumably is the supposition. Besides this, we are committed to the difficulty of deriving the hermaphrodite from the unisexual flower. In both cases the evidence - and there is an abundance-points the other way, namely, that the absence of the perianth or of one set of sexual members is due to reduction. In regard to the catkin families (Amentiferæ) and the like, with naked or apetalous flowers, where obvious links with petalous hermaphrodite forms are not to the fore, surely it is simpler on circumstantial evidence to look upon these flowers as very reduced, than to view them as being primitive in character. Further, it is to be noticed that such flowers are grouped in dense and often complicated inflorescences-an arrangement which cannot be taken as primitive.

A considerable controversy has centred around the supposed primitiveness of the Amentiferæ on other grounds than the character of the flower. This has arisen in part through Treub's classical researches on Casuarina published in $\mathrm{I} 8 \mathrm{gr}$, and in part through the hope of deriving the Angiosperms from the Gnetales through this group. The Amentiferæ consequently received a considerable amount of attention, especially as regards the internal structure of the ovule. All attempts, however, to connect the catkin-trees with the Gnetales have proved abortive, or at any rate far from convincing. Treub's discovery of the peculiar way (chalazogamy) in which the pollen-tube penetrates the ovule in Casuarina, though hailed at first as a primitive character of prime importance, can now only be regarded as secondary and of little or no phylogenetic significance. The Amentiferæ may possess some primitive features in the ovule and in the structure of the wood, but they do not appear to have a monopoly of these. In one point the Magnolian group surpasses them, for certain of its genera lack vessels in the wood, and so are gymnospermous in this respect. It would thus appear quite feasible to regard the Amentiferæ as having come as an early offshoot from Ranalean stock along reduction lines. There is some evidence for their affinity with the Rosales generally, and with the witch-hazels (Hamamelidaceae) in particular. Hutchinson favours this view.

In certain quarters in which the Amentiferous flower has been accepted as primitive, the Ranalean flower has also been admitted as a primitive type. The logical outcome of such an expression of opinion would surely be to infer a polyphyletic, or at least a diphyletic, origin for Angiosperms. But there are grave difficulties in such an inference. At the present time I venture to think that the vast majority of botanists regard the Angiosperms as monophyletic; that is to say, an interrelated assemblage of plants which have arisen from one source. Apart from other considerations, one has only to dwell upon the unique type of embryo-sac and the same kind of stamen (microsporophyll) prevailing throughout the group to be convinced of this. Ruling out, then, the possibility of a mixed origin for Flowering Plants, the derivation of all forms of flowers from the Ranalean pattern, ${ }^{4}$ especially as exhibited in Magnolia and its allies, would appear to be the only feasible one; thus affording a basis upon which to erect a phylogenetic, or at any rate a logical, system of classification.

The Monocotyledons have so far not been mentioned. Though various views have been held in the past regarding their relationship to the Dicotyledons, there is now a consensus of opinion that they have had a dicotyledonous origin. In other words, their ancestors possessed seedlings with two seed-leaves (cotyledons). How the monocotyledonous seedling with its single seed-leaf arose from the dicotyledonous one is still a matter of dispute. The Monocotyledons must perforce have branched off at a very early period, as the two groups are traceable back to rocks of about an equal antiquity.

It is then on morphological rather than geological evidence that the dicotyledonous derivation of the Monocotyledons is favoured. It is difficult to interpret otherwise their peculiarities, such as the single cotyledon, lack of cambium and style of leaf. Consequently, in a new system of classification which professes to be phylogenetic, they should follow, and not precede, as Engler has them, the Dicotyledons. Hutchinson, I believe, intends to place them so. Two points now arise which affect their arrangement. Have they had a single or plural origin from the Dicotyledons? Though no precise answer can yet be given to this query, the present writer sees no cogent reason for regarding them as other than a natural self-contained group. Then it may be asked from what dicotyledonous assemblage of plants can they be derived? The floral features in common between some of the water-lily family (Nymphæaceæ) and the Helobieæ (water-plantain, floweringrush, etc.) suggest something deeper than mere parallelism. It may not therefore be unduly straining affinities to derive the Monocotyledons from the Ranalean plexus. The Helobieæ can then be treated as the primitive group, at any rate so far as floral features are concerned. The question of the origin of the Monocotyledons is largely bound up with that of the habit of their immediate ancestors. Henslow, years ago, suggested an aquatic origin, and though this was seriously challenged by the late Miss Ethel Sargant in favour of a geophilous origin, it cannot yet be dismissed. The truth may lie somewhere between. Just as in the Dicotyledons, lines of both advancement and reduction with respect to the corolla (petals) can be traced. One of the former has ended in the Orchids, with their

4 A hermaphrodite flower, in short, with its members indefinite in number, free from one another, borne spirally on a conical axis and arranged in a free from one another, borne spirally on a conical axis and arranged in a definite sequence on this axis, namely, proceeding from below upwards, first
perianth members with no clear separation into sepals and petals, then perianth members with no
stamens, and finally carpels.

$$
\text { No. } 2888 \text {, VOL. I I } 5]
$$


extreme specialisation for insect-pollination, and one of the latter in the Grasses, well adapted for pollination by the wind. Disregarding the teleology, we believe there is a substratum of truth in the following lines:

They tell us that the homely corn that grows, From russet stem and leaf, our daily bread,

Was once a lily; which by various steps

Of menial work, became degraded thus;

It left its high-born sisters in their robes

Of gorgeous idleness to clothe itself
In this plain dress for common household use. Its bright-hued petals, nectar cup, and store Of fragrance sweet, that insect lovers wooed, It sacrificed; and only wandering winds,

That have no sense of beauty or delight, Now woo its sober blooms with heedless sighs.

But for this noble humbling of itself God has more highly honoured it, to be

The chief support of human beings, made In His own image-rulers of the world.

(To be continued.)

\section{Biographical Byways. ${ }^{1}$}

\section{By Sir Arthur Schuster, F.R.S.}

io. Hermann Helmholtz (I82i-I894), Heinrich Hertz (1858-I894), AND RöNTGEN (I845-I923).

THE names of Helmholtz and Hertz remain connected together in my mind probably because, when I met them towards the end of their lives, the conversation with both mainly turned on the nature of cathode rays. Hertz adhered to the idea that they consisted of vibrations, while Helmholtz from the beginning stood up for the corpuscular theory, and was rather sore that the idea did not originate in his own laboratory. During the few months I was working there, at the end of 1874 , Goldstein was engaged in the important researches which the Royal Society has recognised by the award of the Hughes Medal. His experiments, which showed that the rays emanating from a cathode were strongly repelled by an adjacent parallel electrode, were sufficient to convince Helmholtz that the rays consisted of a projection of negatively electrified matter, but Goldstein did not fall in with this view. "Of course," said Helmholtz to me a few years later, " as soon as Stokes became acquainted with Crookes's experiment he guided him into the right path."

In his early years Helmholtz seems to have been very sensitive to criticism. Roscoe used to relate how he found him once in great distress, complaining that his whole scientific career was endangered because some one had thrown doubt on one of his conclusions.

The Physical Laboratory of Berlin in 1874 contained only three or four rooms, with about a dozen students engaged in researches on a number of subjects mostly suggested by Helmholtz. In his daily rounds he used to discuss scientific problems freely with each in turn. He was as quick as Kelvin in being able to shift his mind quickly from one subject to another, but, in contrast with Kelvin, there was always a gocd deal of the Grand Seigneur in his attitude, and the title of Excellency bestowed upon him was borne with great dignity. He relaxed to some extent in his annual visits to Pontresina, where I received much encouragement from him in my early attempt to form some consistent theory of the passage of electricity through gases.

Her Excellency-his second wife, and a member of the South German aristocracy-was fond of society and gave weekly musical parties at their home in Berlin. She was of a highly strung and nervous temperament. During one of their visits to England they were staying with Roscoe at Manchester, and one morning she came down to breakfast complaining that she had been very ill during the night. She woke her husband, saying:

1 Continued from p. 306.

No. 2888 , voL. I I 5 ]
" Hermann, I am going to die." " That is easier said than done," replied Helmholtz, turning round to sleep again. At one of his visits to Roscoe, he was accompanied by his daughter. The conversation turned on the possibility of flying. "It would be beautiful," said Miss Helmholtz; " one could escape so easily from one's chaperon; but then perhaps girls would be put into cages."

The intimate relations which Helmholtz maintained with Kelvin are referred to in the biography published by Königsberger. I may quote here the passage from a letter written by Helmholtz to his wife while on a visit to Lord Kelvin :

"The former (James Thomson) has a good brain with clever ideas, but he will not listen to anything except about engineering and talks about it at all hours, day or night, so that no other subject of conversation has a chance in his presence. It is amusing to watch each of the brothers (William and James) insisting on explaining something to one another, and neither of them listening to what the other says. But the engineer is more persevering, and generally gets his own way.

"In the meantime I have seen a number of new and ingenious appliances of William Thomson's, and had two interesting days here in consequence. But Thomson's thoughts follow each other so rapidly, that one can only obtain the necessary explanations about the working of his instruments, etc., by a series of questions to which it is difficult to get an answer. How his students can understand him is beyond me, as they cannot permit themselves to make the efforts to keep him to the point, which I could venture upon. All the same, a number of students were working in the laboratory and seemed to know what they were doing. . . . Thomson's experiments did for my new hat. He set a heavy metallic disc, balanced on a point, into rapid rotation, and in order to show me how the disc became immovable by the spin-he struck it with a hammer. The clisc revolted against this treatment and flew off to one side, projecting the iron stand in the opposite direction. The stand split my hat and carried it away. The disc happily did no damage beyond breaking some glasses."

As is well known, the original suggestion that Hertz should undertake the experimental demonstration of the propagation of electrodynamic waves according to Maxwell's theory came from Helmholtz. The research could be undertaken only by one who possessed exceptional abilities both on the theoretical and experimental 